where he was a visiting professor under a Fulbright-Hayes grant.

Peter A. Toma, University of Arizona, is participating in an inter-university consortium of social scientists who are engaged in research mapping for AID's Food for Peace Program.

Rocco J. Tresolini, chairman, department of government, Lehigh University, was one of two recipients of the R. R. and E. C. Hillman award. The award is given annually by the university to faculty members who have contributed most toward the advancement of the interest of the university.

Richard W. van Wagenen has returned to his post as dean of the Graduate School at American
University after two years with the International Bank for Reconstruction and Development.

Ellis Waldron, Montana State University, studied at Harvard Law School during 1963-64 under a Carnegie Foundation fellowship.

RoBert Warren has returned to the University of Washington from a year spent with Resources for the Future, Inc., in Washington, D. C.

Henry Wells, University of Pennsylvania, read a paper at the Sixth World Congress of the International Political Science Association in Geneva.

T. P. Wright, JR., has returned to Bates College after a year's absence spent in India under a Fulbright award.

\title{
STAFF CHANGES
}

\section{New Appointments}

Charles F. Andrain, assistant professor, San Diego State College

ANDREW BAGGs, instructor, University of Florida

Howard BaLL, instructor, Rutgers-the State University

Theodore Becker, University of Hawaii

Dennis E. Beller, instructor, Miami University (Ohio)

William J. Blough, University of Houston

Leroy L. Bradwish, assistant professor, Drake University

Doyle Buckwalter, instructor, Brigham Young University

RoNALD F. BunN, associate professor, Louisiana State University

Ronald H. Chrlcote, assistant professor, University of California at Riverside

William Coplin, assistant professor, Wayne State University

Edmond Costantini, lecturer, University of California at Davis

Phillip Covlter, instructor, University of Massachusetts

LAWrence J. DeNARDis, assistant professor, Albertus Magnus College

Joex R. Dickerson, instructor, Millikin University
John P. EAst, assistant professor, E. Carolina College

JAMES F. ENGEL, assistant professor, New Mexico State University

Lee W. Farnsworth, assistant professor, Brigham Young University

JACK D. FLeER, assistant professor, Wake Forest College

J. Leiper Freeman, professor, Vanderbilt University

Ronert Fried, assistant professor, University of California at Los Angeles

Sterling Hale Fuller, professor and chairman, University of Missouri at Kansas City, effective September, 1964

Douglas S. Gathin, assistant professor, Florida Atlantic University

William Gerlach, associate professor, Eastern Kentucky State College

Donald Gerth, professor, Chico State College

I,ours GoLd, instructor, Oberlin College

John Gunnell, assistant professor, Graduate School of Public Affairs, the State University of New York at Albany

Michael HaAs, University of Hawaii

Harlan Hahn, assistant professor of political science and research associate in the School of Health, University of Michigan

Fred Hanga, Jr., associate professor, Gradu- 
ate School of Public Affairs, the State University of New York at Albany

Charles M. Hardin, professor, University of California at Davis; formerly associate director for Humanities and Social Sciences of the Rockefeller Foundation

Martin J. HaUser, instructor, University of Minnesota

Duane W. Hilu, associate professor, Colorado State University; also research associate of the Social Science Foundation of the University of Denver

Douglas Hobbs, assistant professor, UCLA

Jonn A. Hоввs, assistant professor, San Diego State College

George C. Hoffman, assistant professor, Butler University

John Hutchinson, associate professor and research associate of Industrial Relations at UCLA

David E. Ingersoli, assistant professor, University of Delaware

Lester JaCkson, instructor, Newark College of Arts and Sciences, Rutgers University

George Jenkins, assistant professor, University of Wisconsin at Milwaukee

James E. JernberG, assistant professor, University of Minnesota

Kenneth F. Johnson, assistant professor, Colorado State University, and research associate in the Social Science Foundation of the University of Denver

W. Landis Jones, Waynesburg College

Joyce K. Kallgren, lecturer, University of California at Davis

Henry S. KarieL, associate professor, University of Hawaii

Boyd R. Keenan, professor and head of the department of political science, Purdue University; formerly associate director of the Committee on Institutional Cooperation and visiting professor at Purdue

Samuel Krislov, associate professor, University of Minnesota

Roger A. Kvam, assistant professor, University of Akron

Everett C. Ladd, JR., assistant professor, University of Connecticut
Joseph LaPalombara, professor, Yale University

PAUL M. LEARY, instructor, Rutgers-the State University

Michael Lofchie, assistant professor, UCla

Stuart A. Mackown, instructor, Washington College, Chestertown, Maryland

RICHARD L. MCANaw, Western Michigan University

Robert McNeILL, associate professor, Wayne State University

R. M. MAHOOD, assistant professor, Memphis State University

Frank E. Meyers, instructor, State University of New York at Stony Brook

Diane Monson, assistant professor, Brigham Young University; formerly of Connecticut College for Women

Carl C. Moses, associate professor, Wake Forest College; formerly of Virginia Polytechnic Institute

DaN D. Nimmo, University of Houston; formerly of Texas Technological University

Josef Patyk, assistant professor, University of Dayton; formerly Consul-General of Poland

J. John Penikis, instructor, University of Minnesota

Mrchael D. Reagan, professor, University of California at Riverside; formerly of the University of Syracuse

Jon M. ReinhardT, instructor, Wake Forest College

David E. RePass, assistant professor, University of Minnesota

Harold V. Rhodes, assistant professor, Wake Forest College

Allan Richands, professor and director of the Bureau of Public Administration, Louisiana State University, effective February, 1965

WILLIAM L. RICHTER, instructor, University of Hawaii

Carey G. Rickabaugh, instructor, University of Maryland, effective January, 1965

RoBert E. RIGGs, associate professor, University of Minnesota; formerly of Brigham Young University 
EDWARD T. ROWE, instructor, University of Connesticut

Leonard I. RUChelman, assistant professor, Alfred University

Rudolph J. Rummel, assistant professor, Yale University

Mary Clarke Santopolo, associate professor, Eastern Kentucky State College

Ashley L. Schiff, associate professor, University of New York at Stony Brook; formerly at the School of Public Administration of the University of Southern California

Carl L. Schweinfurth, assistant professor, Bethany College

Richard D. Sears, instructor, Wake Forest College

Josef Silverstern, associate professor, Rutgers-the State University

Robert Smith, Western Michigan University

William Standing, assistant professor, Wayne State University

Murray S. Stedman, professor and chairman of the department of government at Trinity College, Connecticut

Barbara B. Stevens, assistant professor, University of Connecticut

Phillippa Strum, instructor, Newark College of Arts and Sciences at Rutgers University

Kirk Thompson, assistant professor, Reed College

WoODWORTh G. ThrombleY, associate professor, Institute of Public Administration, University of Indiana; for the last three years, principal advisor to the Indiana UniversityThammasat Public Administration program in Bangkok

REXFord G. TUGWELL, research professor, Southern Illinois University, effective March, 1965

Manfred Vernon, chairman of political science, Western Washington State College at Bellingham; formerly of the University of Alabama

LaARY L. WADE, assistant professor, Charlotte College, North Carolina

J. RICHARD WAGNER, instructor, University of Arizona

JoSEPH WILLARD, associate professor, University of Toledo
Fred W. Willhoite, assistant professor, Louisiana State University

Carwin C. Williams, Brigham Young University

William R. Willoughby, senior professor, University of New Brunswick, Fredericton, N. B.; formerly of St. Lawrence University

CaLvin WoodWARD, lecturer, University of New Brunswick

Amos Yoder, lecturer, University of California at Davis

Virgil B. Zimmerman, associate professor, Graduate School of Public Affairs, the State University of New York at Albany; formerly head of the Bologna program of the University of California

\section{Temporary and Visiting Appointments, 1964-65}

David Bane, U. S. Foreign Service Officer: visiting lecturer, University of Iowa

Eugenio Benedetti, University of Padua: visiting assistant professor, Ohio Wesleyan

Clarence A. Berdahl, professor emeritus, University of Illinois: distinguished visiting professor, University of Delaware, spring semester, 1965

Lowell W. Culver, assistant professor, Pacific Lutheran University

Howard Dean, Portland State College: visiting professor, University of Washington, autumn, 1964

Rupert Emerson, Harvard University: visiting professor, UCLA, spring semester, 1965

Robert H. Ferrell, University of Indiana: visiting professor, University of Connecticut

Gerald Friedberg, acting assistant professor, University of California at Davis

Emmetr Graybill, instructor, Allegheny College

Claude H. Heyer, visiting instructor, University of Idaho

James Hurley, instructor, Dennison University

Raghavan IYer, lecturer, UCLA

Yung-Hwan Jo, assistant professor, Colorado State University

Cuaudrus O. Johnson, Washington State University: visiting professor, Montana State Uni- 
versity, 1963-64 and winter and spring quarters, 1965

Ralph Johnson, lecturer, Allegheny College

A. D. H. KAPLAN, Brookings Institution: distinguished visiting professor, Graduate School of Political Affairs, State University of New York at Albany

Todd R. LAPorte, University of Southern California: visiting assistant professor, Stanford University

EDward G. Lewis, University of Illinois: Chester W. Nimitz professor of social and political philosophy, Naval War College

Dennis A. Livingston, acting assistant professor, University of California at Davis

James S. Nyman, University of California at Davis: visiting assistant professor, University of Arizona

KAN ORI, visiting professor, University of Minnesota

David F. Paulsen, Jr., University of Washington: visiting assistant professor and research specialist, Institute of Government Research, University of Arizona

De Vere Pentony, San Francisco State College: visiting professor, University of Iowa

Walford H. Peterson, Bethel College (St. Paul): visiting professor, University of Minnesota

Bhagwati P. K. Poddar, assistant professor, Illinois State University

KarL M. SchmidT, Syracuse University: visiting professor, University of Hawaii

David Scort, Southwest Missouri State College: visiting professor, Southern Illinois University

Alan Seltzer, acting assistant professor, UCLA

Eli Silvarman, lecturer, Allegheny College

Lea H. Williams, Brown University: visiting lecturer, Fletcher School of Law and Diplomacy, Tufts University

David Wilson, acting assistant professor, UCLA

Javan Tabibian, lecturer, UCLA

Louis F. WECHsLER, acting assistant professor, University of California at Davis

Brong-Man Yoon, assistant professor, Colorado State University
SePher Zabih, assistant professor, Oherlin College

PaUl E. Zinner, University of California at Davis: visiting professor, National War College

\section{Other Appointments}

Bruce Adrinson, Hofstra University: assistant dean of faculty

Totten J. Anderson, UCLA : chairman of the department of political science

Carol E. Baumane, University of Wisconsin at Milwaukee: director of the Institute of World A ffairs Education

Ronald ChIlcote, University of California at Riverside: coordinator of the program on Latin American research

Manning J. Dauer, University of Florida: director of the Division of Social Sciences at the University of Florida

Donald R. Gerth, Chico State College: dean of students

M. Judd Harmon, Utah State University: chairman, department of political science

Herbert Kaufman, Yale University: chairman, department of political science

Young W. KIHL. Juniata College, chairman, department of political science

Gerard J. Mangone, Syracuse University: associate dean for academic programs, Maxwell Graduate School of Citizenship and Public Affairs, Syracuse University

Norman Mellen, University of Hawaii : chairman of the department of political science

Gene Edward Rainey, American University: assistant dean of the Graduate School

JAMEs R. Roach, associate professor, University of Texas: coordinator of international and foreign area programs

Donald R. Shea, University of Wisconsin at Milwaukee: dean of international studies and programs

Robert Stephens, formerly Chief of Eastern and Southern African Office of African Programs, State Department: assistant director of East Asian Studies, Syracuse University

James A. Storina, Colgate University: provost

Robert Williams, East Carolina College: associate dean of the College and dean of the School of Arts and Sciences 


\section{Promotions}

To the rank of assistant professor:

Albert L. Gastman, Trinity College, Hartford, Connecticut

Marshatl N. Goldstein, University of Oregon

RAY C. Hillam, Brigham Young University

JAMEs E. NAdonly, Western Michigan University

Knud Rasmussen, Colgate University

Thomas M. Scotт, University of Minnesota

To the rank of associate professor:

James E. Anderson, Wake Forest College

Charles H. Backstrom, University of Minnesota

Ben G. Burnett, Whittier College

Alfred B. Clubak, University of Florida

Roland H. Ebel, Western Michigan University

Ahmad R. Haffar, State University of New York at New Paltz

Clarke Hagensick, University of Wisconsin at Milwaukee

Robert KaUfman, Western Michigan University

Samuel C. Patterson, University of Iowa

Gerald M. Pomper, Rutgers-the State University

Roberta S. Siged, Wayne State University

H. Frank Way, University of California at Riverside

T. P. Wright, Bates College

G. Ross Stephens, University of Connecticut
To the rank of professor:

George S. Blair, Claremont Graduate School

J. Leo Cefrin, Colorado State University

Lane Davis, University of Iowa

Stephen T. EARLY, DePauw University

Stanley H. Friedelbaum, Rutgers-the State University

Philip O. Foss, Colorado State University

Charles D. Farris, University of Florida

Milton Greenberg, Western Michigan University

ROBERT HoLT, University of Minnesota

Karel Hulicka, State University of New York at Buffalo

Fred Kort, University of Connecticut

Manoucher Vahdat, Northwestern State college

\section{Retirements and Resignations}

PhILIP W, Buck will reach emeritus standing at Stanford University in August of 1965, after thirty years in the department of political science.

Marshall Knappen, H. Fletcher Brown professor of history and political science at the University of Delaware, retired on February 1, 1965.

Charles M. Kneier, professor of political science at the University of Illinois since 1930, has retired.

MYRon R. RUBINOFF of the University of Toledo has resigned.

Walter Sharp, professor of political science at Yale University since 1951, retired in June, 1964.

LLOYD SHORT, professor of political science, University of Minnesota, will retire in June, 1965.

JOsEPH E. BLACK has resigned as chairman of the department of government at Miami University (Ohio) to become director of Humanities and Social Studies with the Rockefeller Foundation.

The Inter-University Consortium for Political Research will sponsor seminars in Quantitative Political Analysis, Community Political Analysis, and Methods of Historical Analysis at Ann Arbor, Michigan, this summer, with expenses of participants partially borne by grants of the National Science Foundation. Information may be obtained from the ICPR, P. O. Box 1248, Ann Arbor, Michigan 48106. 